\title{
- ШОУ ЯК ФЕНОМЕН МАСОВОÏ КУЛЬТУРИ: СУТНІСНІ ОЗНАКИ Й ФУНКЦІї
}

\section{- Кириченко Альона Олегівна}

\section{Аспірантка,} ORCID: 0000-0002-6237-832X, e-mail: alenakiri4enko@gmail.com, Київський національний університет культури і мистецтв, вул. Є. Коновальця, 36, Київ, Україна, 01133

\section{- Для цитування:}

Кириченко, А.О. (2021). Шоу як феномен масової культури: сутнісні ознаки й функції. Питання культурології, (38), 109-119. doi: https://doi.org/10.31866/2410-1311.38.2021.245783.

\section{- Анотація}

Мета статті - аналітично осмислити визначення поняття «шоу», розкрити функції та сутнісні ознаки концертних шоу в сучасній масовій культурі. Методологія дослідження ґрунтується на системному підході (для розкриття взаємозв'язків між різними видами шоу, виявлення та концептуалізації їх функціональних характеристик); аналітичному та компаративному аналізі (для уточнення понятійного апарату). Наукова новизна одержаних результатів полягає у з'ясуванні сутнісних рис шоу як культурного продукту масового суспільства, таких як публічність, масовість, видовищність, висока технологічність, орієнтація на глядача, краса, яка проявляється в стані артиста і зовнішньому антуражі. Висновки. Зазначено, що технічні відкриття, демократичні перетворення, урбаністичні процеси XIX-XX ст. стали основою створення нових соціально-економічних відносин, прояву нового типу культури - масової, що спричинило розвиток нових тенденцій в культурі та мистецтві. Проаналізовано багатозначність терміна «шоу» в культурологічному дискурсі: шоу може називатися телевізійна, радіопрограма, театральна вистава, масове видовище, модний показ. Визначено, що під концертним шоу розуміється концертна програма - сольна чи збірна, яка характеризується видовищністю, масовістю, яскравістю, технологічністю виражальних засобів. Сучасне шоу - це більше «як?», аніж «що?», тобто украй ефректно, помпезно, захопливо, різнобарвно, динамічно та оригінально, адже сучасний глядач прагне незабутніх вражень. Виокремлено основні функції шоу: гедоністична, компенсаторна, комунікативна, інформативна та пізнавальна, функція емоційного регулювання. Наголошено на тому, що концертне шоу має сприяти розвитку творчого потенціалу аудиторії, розширювати світогляд, надавати нову інформацію. Найвищою метою організаторів шоу можна вважати підвищення загальної культури суспільства.

Ключові слова: шоу; видовище; концертне шоу; масова культура 


\section{- Вступ}

Усталений розподіл на елітарну та масову культуру в суспільстві призвів до того, що перевага завжди надавалася першій, бо саме вона відзначалася високими естетичними смаками та глибиною смислів. Але й масова культура позитивно вплинула на суспільство: створила умови відпочинку та релаксації. Глобальне поширення продуктів масової культури - телебачення, радіо, кінематограф, масова література, популярна музика, образотворче мистецтво - особливо завдяки мережі Інтернет, сприяє масштабному споживанню цієї продукції суспільством. Одним з цих продуктів стає і шоу як особливий видовищний тип програм, призначений для задоволення потреб масового глядача. Творці різнофрорматних телевізійних шоу запрошують глядачів до перегляду програм; артисти, щоб залучити якомога більше прихильників, продають квитки на свої концертні шоу; радіоведучі закликають вмикати вранці їх радіохвилю, щоб почути ранкове шоу. Чим більше проданих квитків - тим краще, чим вищі рейтинги — тим більший успіх. Тому розважальна сфера сьогодення рясніє різножанровими шоу, створеними для релаксації, рекреації та ескапізму масового глядача в ірреальні світи. Варто також згадати про авто чи авіашоу, політичне шоу. Приставка «шоу» автоматично асоціюється з масовістю, розважальністю, видовищністю. Концертні шоу сьогодення виходять на нову ланку розвитку і дивують глядачів новими технологічними підходами, синтетичними поєднаннями усіх видів і жанрів мистецтв. Шоу, вплітаючись в естетику масової культури і орієнтуючись на масового глядача, зазнають її впливу. Адже сучасний масовий глядач через блискавичне розповсюдження і вжиток візуально-аудіальної інформації запрограмований на гостре відчуття здивування від перегляду чи прослуховування, бо інакше йому стає нудно. Термін «шоу» тривалий час циркулює в культуро-мистецькому просторі, але «концертне шоу» використовується здебільшого в практичній сфері (наприклад, в номінаціях різноманітних премій та на афрішах, які інформують про виступ артистів). Це виразний приклад того, коли не теорія дає життя практиці, а практика змушує замислитися над теоретичним контекстом. Тому стає актуальним дослідження сутності поняття шоу та його характерних рис і фрункцій в сучасному соціокультурному просторі. Адже більша частина соціуму упереджено ставиться до шоу-програм, вбачаючи в них тільки одну основну функцію — гедоністичну, хоча вона $€$ основою для всіх видовищних заходів.

Масова культура є предметом вивчення у працях Дж. Сторі, Л. Саєнкова. Шоу в контексті масової культури дослідила І. Коротаєва (Коротаева, 2008). Шоу як безпосередній об'єкт дослідження у розрізі шоу-бізнесу та продюсування шоу-програм постає у працях А. Жаркова (2009). Шоуїзацію та шоутизацію культури розглядають у своїх роботах К. Акопян (2008), Н. Дубовик (2010). Культурологічний аналіз шоу провела Т. Ванченко (2013), шоу-технології як соціальні комунікації дослідила А. Скрипка (2010), принципи оформлення масових видовищ - М. Крипчук (2011). Практичні режисерські рекомендації при створенні та організації шоу висвітлили у своїх роботах відомі режисери сучасності О. Боднарчук (2020) та О. Сєченов (Сеченов, 2021). Проте сутнісні ознаки та функції шоу як форми масової культури недостатньо висвітлені в культурологічному дискурсі. 


\section{- Мета статті}

Мета статті - аналітично осмислити визначення поняття «шоу», розкрити функції та сутнісні ознаки концертних шоу в сучасній масовій культурі. Методологія дослідження ґрунтується на системному підході (для розкриття взаємозв'язків між різними видами шоу, виявлення та концептуалізації їх функціональних характеристик); аналітичному та компаративному аналізі (для уточнення понятійного апарату).

\section{- Виклад матеріалу дослідження}

Кінець XIX - початок XX ст. виявилися сприятливою добою для фрормування масової культури. Потужний розвиток техніки, поява інноваційних винаходів, індустріалізація, значний приріст міського населення і, як наслідок, - розвиток міст, тиражування витворів мистецтва, зміна етичних норм і моральних цінностей, стандартизація способу життя, смаків, методів спілкування, манери одягатися, відпочинку та ін. стає початком епохи масової культури і появи людини «середнього класу». Але стверджувати, що масова культура почала формуватися наприкінці XIX ст. було б необачно, адже передумовами появи цього типу культури були видовищні форми різних часів, які передбачали наявність масової аудиторії: давньогрецькі обрядові святкування, давньоримські спортивні змагання, середньовічні містерії, лицарські турніри, масові розваги під час бенкетів та балів, маскаради, карнавали. Водночас К. Акопян (2008), вивчаючи це питання в історичній ретроспективі, визначає шоу як «насамперед видовище, потребу в якому людина виявляла ще в глибоку давнину (зокрема, мисливські та військові, релігійні та магічні, весільні та похоронні й інші ритуали, які можна розглядати як загальнокультурне походження шоу, вимоги “хліба і видовищ”, що мають вже безпосереднє відношення до споживчої культури) і привабливість якого досягається максимально можливим оголенням зовнішнього і відсутністю більш-менш значущого інтересу до внутрішнього, змістовного». Одним з головних елементів масової культури в ті часи й дотепер була і залишається видовищність, одним із засобів впливу - наявність яскравих образів, що характерне і для шоу.

Становлення та розквіт масової культури відбувається в XX ст. Саме в цей час, а точніше 1944 року, з'являється термін «масова культура» в роботі Д. Макдональда. Упродовж наступних років відбувалося критичне осмислення явища в соціально-економічному, ідеологічному, психологічному та естетичному векторі. I якщо на початку XX ст. в закордонних наукових колах переважала думка щодо негативного впливу масової культури (пасивність сприйняття, споживацький характер, зміна ціннісних орієнтирів у бік стереотипності, розважальності), то наприкінці століття позначилися позитивні настрої в розвитку масового суспільства (адже масова культура не загрожує і не руйнує високу культуру, а тільки демократизує, що є благом для суспільства). Саме тоді, наприкінці XX ст., «народився новий жанр, який отримав широке розповсюдження і популярність, - шоу-програми» (Коротаева, 2008). Сьогодні масова культура стає не тільки панівною культурою сучасного соціуму, а й простором, в якому з'являються, функціонують та активно розвиваються всі види мистецтва. 
Сучасні шоу орієнтовані на масові уподобання та характеризуються стереотипними зв'язками зі стандартизацією та уніфікацією смислів та образів для легкого глядацького сприйняття. Водночас А. Скрипка (2010) зазначила, що «розвиток технологічних можливостей вивів репрезентативну функцію видовища на новий рівень, внаслідок чого фрормується нова комунікативна практика, яка, з одного боку, синтезувала в собі досягнення й характеристики різноманітних традиційних видовищних практик, а з іншого - стала унікальним явищем сьогодення - шоу».

Термін «show» $є$ англіцизмом і перекладається як: 1) показ, демонстрація, демонстрування; 2) виставка; 3) пишна процесія; 4) видовище, спектакль, вистава; 5) кіносеанс; 6) спорт. виступ; 7) авіаційне свято, показові польоти літаків; 8) вечірка, бенкет; 9) картина, видовище; 10) зовнішній вигляд, видимість; 11) фрілософр. явище, зовнішня форма; 12) показна пишнота (парадність), зовнішня ефректність (Гороть та ін., 2010). У перекладі з англійської мови дієслово «to show» означає: 1) показувати; 2) з'являтися; 3) подавати (приклад); 4) пояснювати, роз'яснювати, учити; 5) виставляти, експонувати, демонструвати; 6) зображувати; відтворювати; 7) грати, показувати спектакль; 8) спорт. виступати на рингу (бокс); 9) виявляти, з'ясовувати, викривати; 10) висловлювати, виражати, проявляти (почуття). Отже, в самому значенні слова прихована багатозначність трактувань і можливість використання цього терміна в різних сферах культури та мистецтва. Тобто цим поняттям можуть називатися заходи різного спрямування, які мають на меті щось продемонструвати, показати, донести певну візуальну або аудіальну інформацію з орієнтацією на сприйняття і оцінку певної аудиторії. Загалом сукупність визначень шоу можна представити як:

- інтертеймент: «театральний перформанс, телевізійна або радіопрограма розважального спрямування (радіо / телевізійне / сценічне шоу)»; «публічний івент, на якому демонструються споріднені групи речей (модний показ чи квіткове шоу)» (Cambridge Dictionary, n.d.);

- «масове видовище, один з головних елементів «масової культури», розрахований на психологічний вплив на глядача. Цим зумовлена зовнішня претензійність, крикливість і часта вульгарність подібних заходів, апеляція до посередніх смаків глядача» (Радугин, 1997, с. 449);

- «вистава (в широкому сенсі слова), яка нерідко супроводжується проведенням будь-яких заходів у громадському та культурному житті (конкурси краси, вручення театральних, літературних премій, кінопремій та ін.)» (Хоруженко, 1997, c. 551);

- «форма артизації, своєрідна вистава, театралізоване видовище, яке супроводжує заходи громадського і культурного життя» (Лисаковский, 2002, c. 227);

- «яскраве ефректне видовище, вистава (концертне шоу, естрадне шоу, циркове шоу, телевізійне шоу); чиї-небудь дії, заходи, спрямовані на привернення до себе уваги (політичне шоу, передвиборче шоу)» (Бибик \& Сюта, 2006, с. 614);

- «вистава розважально-естрадного жанру за участю зірок естради, цирку чи джаз-оркестру; про те, що привертає увагу, розраховане на зовнішній ефеект» (Нечволод, 2007, с. 758); 
- «масове театралізоване дійство, побудоване за ігровим принципом і має видовищний характер» (Дубовик, 2010);

- «одна з найяскравіших форм сучасної розважальної культури, що охоплює основні відмінні риси постмодернізму, такі як синтез, монтаж, фрагментарність і амбівалентність» (Коротаева, 2008);

- «феномен культури, в якому провідну роль відіграє зовнішнє, фрормальне, зв'язки якого з сутнісним, глибинним якщо і не відкидаються, то не можуть розглядатися як ті, що мають істотне значення» (Акопян, 2008);

- «сучасна культурна форма, є символічним художнім витвором, підпорядкованим певному жанру, основу якого складає поєднання засад відтворення традиційних видовищних форм із сучасними технологічними можливостями візуалізації з урахуванням суспільної сфрери, в межах якої відбуватиметься трансляція результатів цього втілення»; «під шоу як культурним продуктом розуміється конкретна подія, яка відбувається в просторі та часі, представляє поєднання принципів створення символічних художніх витворів, з одного боку, та комерційно-вигідних проєктів - з іншого, зазвичай реалізується на засадах масової культури, має яскраво виражений видовищний та розважальний характер, а також латентну спонукальну спрямованість» (Скрипка, 2010);

- «форма, явище, що починає входити у вже традиційні форми побутування мистецтва і культури. Внаслідок синтезу шоу і естради утворюються музично-розважальні естрадні шоу; шоу і телебачення — різні телевізійні шоу-програми; шоу і культурних подій соціального життя - конкурси краси, вручення театральних, літературних, кінопремій та ін.» (Ванченко, 2013, с. 78).

Аналіз наведених визначень дає можливість констатувати, що шоу, функціонуючи на засадах масової культури, щільно вкоренилося в сучасному суспільстві. Насамперед дослідники визначають шоу як виставу, видовище, яке демонструється публічно для великої кількості глядачів з метою розважити, здивувати, вплинути на емоційний настрій публіки, інколи навіть шокувати їі. Але, пройшовши етапи явища, феномена культури, шоу стає вже усталеним культурним продуктом сьогодення. Важливо відзначити масовий характер заходу, його розважальну спрямованість, легкість, необтяжливість сприйняття. Не можна ігнорувати визначне значення розваг у сучасному бурхливому житті, коли робота стає досить напруженою і суспільство потребує викиду емоцій, розслаблення, підвищення настрою. Експресивність, контрастність, швидка зміна відчуттів, несподівані вирішення сценічних ситуацій - ось що очікує глядач від шоу. І. Коротаєва навіть називає шоу «згущеним видовищем», тобто максимум різноманітності, максимум виразності (Коротаева, 2008).

Концерні шоу, по суті, є концертними програмами - сольними чи дивертисментними (збірними), які відзначаються надзвичайною видовищністю, яскравістю і технологічністю виражальних засобів. Сучасне шоу - це більше «як?», аніж «що?», тобто украй ефектно, помпезно, захопливо, різнобарвно, динамічно, надзвичайно і навіть франтастично. «Наразі шоу-програма стає провідною формою шоу-бізнесу та відображає сучасний стан суспільства» (Жарков, 2009 , с. 8). Не кожен концерт, вистава чи церемонія нагородження може бути шоу, адже шоу — це гранична міра грандіозності та насиченості дії. I це виокрем- 
лює одну з найважливіших його сутнісних ознак - видовищність, яка досить часто стає домінантною поряд з такими ознаками, як масштабність, грандіозність, модність, яскравість, акцент на зорове сприйняття. Відомий український режисер О. Боднарчук (2021) зазначає: «...у шоу є своя естетична категорія, яка виокремлює його як абсолютно самостійний вид сценічного мистецтва шоу "розважає" красою, завжди "радує око". Краса тут виражається не тільки в зовнішніх ознаках - особливих костюмах, декораціях, світловому оформленні, краса шоу - це також і внутрішній стан артистів у контексті оточуючого їх художнього світу. Краса - одна з важливих умов шоу» (с. 31).

Концертне шоу сьогодні важко уявити без використання спеціальної техніки й технологій. Світлове обладнання, якісна звукова апаратура, світлодіодні екрани для трансляції віджеїнгу, різнорівневі сценічні конструкції, лазери різних кольорів, димові та піротехнічні ефекти, голографічні проєкції, 3D-моделювання, робототехніка - все це стало обов'язковими елементами створення захопливої атмосфери шоу. Річ у тому, наскільки оригінально і по-новому зможуть режисери використати ту чи іншу технологію. У сучасних концертних шоу різні жанри сценічного мистецтва синтезуються, гібридизуються між собою та підсилюються досі небаченими технологіями: в окремому концертному виступі артиста поєднуються музика, вокал, пластика, балет, лазерні промені, графіка на екранах, феєрверк, телевізійні засоби прямої трансляції та модний дизайнерський одяг, в якому виступає артист. Синтез і відзначає яскраву видовищність, оригінальність такого типу шоу. Як визначав у своєму дослідженні Я. Ратнер (1980), «Видовищність - це система експресивно-динамічних ефектів та засобів залучення глядача у дійство із заздалегідь розрахованим результатом» (с. 8-9). Одними з таких засобів, ефектів на сучасному етапі стають актуальні інноваційні технології, які поступово «вплітаються» в сценічний простір. Адже «шоу - це життя», як стверджує О. Сєченов (Сеченов, 2021). «Будь-яке шоу створюється як окремий світ зі своїми правилами та законами, але цей світ відображення нашого життя і нас самих» (с. 8).

Зміна життя в бік техногенності призвела до того, що сучасна публіка стає вибагливішою, очікує побачити оригінальні ідеї, актуальні, модні тенденції в сценічному просторі, відчути ефект здивування від «пишного» технічного, декораційного антуражу. I це полягає не в великій кількості різноманітних художніх засобів, а у вдалому і виправданому їх використанні. Утім, це не скасовує ретельно продуманої драматургічної основи заходу та чіткої ідеї, без якої, на жаль, неможливо створити емоційно насичене шоу. Задум визначає зміст концертного шоу, його тему, ідею і як його зміст буде розкривати фрорму і порядок композицій, яка буде логіка переходу від номера до номера, темпоритмічність дії і відповідно визначатиме атмосферу заходу. А створення атмосфери - одна з найголовніших і складних проблем при постановці шоу. Зокрема, визначним компонентом концертних шоу є безпосередній контакт публіки з артистом, обмін енергією, адже живий виступ неможливо замінити відеокліпами чи просто прослуховуванням пісень. Під час шоу глядач відчуває енергетику артиста і від цього фрормується задоволення, піднесення настроїв, амплітуда емоційного насичення публіки. 
Шоу може не тільки розважати, а й транслювати важливі актуальні меседжі, комунікувати з аудиторією - інформація може бути «закодована» у візуальному ряді, у спічах виконавців чи коментарях ведучих. Невипадково окремі дослідники вбачають у шоу «форму псевдокомунікативного спілкування, що має характер масового видовища, технологічно орієнтовану на закріплення в аудиторії потрібних організаторам вражень та оцінок, зокрема й на невербальному рівні» (Стаметов, 2008, с. 14). Шоу має не тільки розважати, а й сприяти розвитку творчого потенціалу аудиторії, розширювати світогляд, надавати нову інформацію. Найвищою метою організаторів шоу можна вважати підвищення загальної культури у суспільстві. «Сьогодні масова культура виконує функцію, яку колись виконувала класична культура, а саме орієнтує, хоч і не в тому обсязі, як раніше, людей на моральні цінності, що панують в суспільстві. I в кращих своїх зразках театралізовані вистави, естрадні видовища не тільки розважають і відволікають глядача, а й опосередкованим чином виховують його» (Крипчук, 2011, c. 164).

Враховуючи естетичний характер сучасних шоу і те задоволення, яке шоу надає своїм глядачам, можна констатувати виконання ним функції емоційного регулювання. Компенсаторна фрункція дає змогу глядачеві відчути ті переживання, почуття, емоції, яких йому не вистачає в повсякденному житті. Не можна оминути гедоністичну функцію - задоволення від перегляду та прослуховування концертних шоу — одне з головних завдань, яке стоїть перед організаторами шоу. Демонстрація сценічних технологічних новинок та модних тенденцій виконують інфрормативну, пізнавальну функцію культури, а масовий характер шоу відповідає комунікативній функції.

\section{- Висновки}

Виникненню масової культури сприяв науково-технічний прогрес, масштабна індустріалізація, урбанізація та розвиток засобів масової комунікації (друк, радіо, телебачення). Сучасні шоу виникли як культурний продукт масового суспільства і мають попит серед глядачів, поціновувачів елітарного та масового мистецтв. Популярність сучасних шоу в мистецьких, політичних, адміністративних та освітніх практиках свідчить про вже сталу вкоріненість та органічну «вмонтованість» шоу в соціокультурні процеси сучасного суспільства. Як форма масової культури, шоу характеризується яскравістю, строкатістю, надзвичайною легкістю в його сприйнятті завдяки створенню піднесеної емоційної атмосфери, що приваблює публіку. Кожен концерт, вистава чи церемонія нагородження переформатувалися сьогодні в шоу і такий підхід збільшив їхню комерціалізацію.

Видовищність, масовість, розважальність, масштабність, грандіозність, висока технологічна база, акцент на зорове сприйняття, адже візуальна інформація стає панівною, кліповість, використання великої кількості спецефектів, модність, яскравість, ефект подиву, орієнтація на вподобання глядача стають основними сутнісними ознаками концертних шоу сучасності.

Концертні шоу впливають на формування естетичних смаків публіки, яка їх відвідує. Глядацьке сприйняття залежить від соціально-психологічних та творчоорганізаційних чинників, тому варто зауважити, що для підвищення емоційного 
тонусу публіки, її естетичних смаків потрібно ретельно продумувати, вибудовувати, планувати концертну програму, прагнути до оригінальних сценічних ідей, грамотно впроваджувати їх в сценічний простір, не ігнорувати змістовність, завершеність дії, щоб концертне шоу відповідало темпам, ритмам сьогодення.

\section{- Список використаних джерел}

Акопян, К. 3. (2008). Шлягеризация шоуизирующейся культуры. http://karen-akopyan. com/shlyager.html

Бибик, С. П., \& Сюта, Г. М. (2006). Словник іншомовних слів: тлумачення, словотворення та слововживання. Фоліо.

Боднарчук, О. В. (2020). Как создать грандиозное шоу. ТАК видавництво.

Ванченко, Т. П. (2013). Культурологический анализ понятия «ШОУ». Вестник ВГИК, (17), 76-84.

Гороть, Є.І., Коцюк, Л. М., Малімон, Л. К., \& Павлюк, А. Б. (2011). Великий англоукраїнський словник. Нова книга; Ранок.

Дубовик, Н. (2010). Шоутизация современной культуры. МІСТ: Мистецтво, історія, сучасність, теорія, (7), 224-233

Жарков, А. Д. (2009). Продюсирование и постановка шоу-программ. МГУКИ.

Коротаева, И. В. (2008). Шоу-программы как френомен массовой культуры. Вестник Казанского государственного университета культуры и искусств, (1), 29-31.

Крипчук, М.В. (2011). Проблеми створення масового театралізованого видовища (принципи художнього оформлення). Наукові записки Тернопільського національного педагогічного університету імені Володимира Гнатюка. Серія: Мистецтвознавство, (2), 163-168.

Лисаковский, И. Н. (2002). Художественная культура: термины, понятия, значения. РАГС.

Нечволод, Л. І. (Уклад.). (2007). Сучасний словник іншомовних слів (Н. В. Тучина, Ред.). Торсінг плюс.

Радугин, А. А. (Ред.). (1997). Энциклопедический словарь по культурологии. Центр.

Ратнер, Я. В. (1980). Эстетические проблемы зрелищных искусств. Искусство.

Сеченов, А. (2021). Шоу - это жизнь. PRINTLETO.

Скрипка, А. О. (2010). Шоу-технології як фрорма соціальної комунікації [Автореферат дисертації кандидата соціологічних наук, Харківський національний університет імені В. Н. Каразіна].

Стаметов, В. В. (2008). Природа шоу как массовой псевдокоммуникации [Автореферат диссертации кандидата социологических наук, Тамбовский государственный университет им. Г. Р. Державина].

Хоруженко, К. М. (1997). Культурология: Энциклопедический словарь. Феникс.

Cambridge Dictionary. (n.d.). Show. Retrieved September 8, 2021, from http://surl.li/altof

\section{- References}

Akopyan, K. Z. (2008). Shlyagerizatsiya shouiziruyushcheisya kul'tury [Chartbuster of Show Culture]. http://karen-akopyan.com/shlyager.html [in Russian].

Bodnarchuk, O. V. (2020). Kak sozdat' grandioznoe shou [How to Create a Grand Show]. TAK vidavnitstvo [in Russian]. 
Bybyk, S. P., \& Siuta, H. M. (2006). Slovnyk inshomovnykh sliv: tlumachennia, slovotvorennia ta slovovzhyvannia [Dictionary of Foreign Words: Interpretation, Word Formation and Word Usage]. Folio [in Ukrainian].

Cambridge Dictionary. (n.d.). Show. Retrieved September 8, 2021, from http://surl.li/altof [in English].

Dubovik, N. (2010). Shoutizatsiya sovremennoi kul'tury [Showtization of modern culture]. MIST: Mistetstvo, Istoriya, Suchasnist', Teoriya, (7), 224-233 [in Russian].

Horot, Ye. I., Kotsiuk, L. M., Malimon, L. K., \& Pavliuk, A. B. (2011). Velykyi anhlo-ukrainskyi slovnyk [Large English-Ukrainian Dictionary]. Nova knyha; Ranok [in Ukrainian].

Khoruzhenko, K. M. (1997). Kul'turologiya [Culturology]: Encyclopedic Dictionary. Feniks [in Russian].

Korotaeva, I. V. (2008). Shou-programmy kak fenomen massovoi kul'tury [Show programmes as a phenomenon of mass culture]. Bulletin of Kazan State University of Culture and Arts, (1), 29-31 [in Russian].

Krypchuk, M. V. (2011). Problemy stvorennia masovoho teatralizovanoho vydovyshcha (pryntsypy khudozhnoho oformlennia [Problems of creating a mass theatrical spectacle (principles of decoration)]. Naukovi Zapiski Ternopil's'kogo Nacional'nogo Pedagogičnogo Universitetu Imeni Volodimira Gnatûka. Seriâ: Mistectvoznavstvo, (2), 163-168 [in Ukrainian].

Lisakovskii, I. N. (2002). Khudozhestvennaya kul'tura: terminy, ponyatiya, znacheniya [Artistic Culture: Terms, Concepts, Meanings]. RAGS [in Russian].

Nechvolod, L. I. (Comp.). (2007). Suchasnyi slovnyk inshomovnykh sliv [Modern Dictionary of Foreign Words] (N. V. Tuchyna, Ed.). Torsinh plius [in Ukrainian].

Radugin, A. A. (Ed.). (1997). Entsiklopedicheskii slovar' po kul'turologii [Encyclopedic Dictionary of Cultural Studies]. Tsentr [in Russian].

Ratner, Ya. V. (1980). Esteticheskie problemy zrelishchnykh iskusstv [Aesthetic Problems of the Performing Arts]. Iskusstvo [in Russian].

Sechenov, A. (2021). Shou - eto zhizn' [Show is Life]. PRINTLETO [in Russian].

Skrypka, A. O. (2010). Shou-tekhnolohii yak forma sotsialnoi komunikatsii [Show Technology as a Form of Social Communication] [Abstract of PhD Dissertation, V. N. Karazin Kharkiv National University] [in Ukrainian].

Stametov, V. V. (2008). Priroda shou kak massovoi psevdokommunikatsii [The Nature of the Show as Mass Pseudo-communication] [Abstract of PhD Dissertation, Derzhavin Tambov State University] [in Russian].

Vanchenko, T. P. (2013). Kul'turologicheskii analiz ponyatiya "ShOU" [Cultural analysis of the concept of "SHOW"]. Vestnik VGIK, (17), 76-84 [in Russian].

Zharkov, A. D. (2009). Prodyusirovanie i postanovka shou-programm [Production and Staging of Show Programmes]. MGUKI [in Russian]. 


\title{
SHOW AS A PHENOMENON OF MASS CULTURE: INTRINSIC FEATURES AND FUNCTIONS
}

\author{
- Alona Kyrychenko \\ - PhD student, \\ ORCID: 0000-0002-6237-832X, e-mail: alenakiri4enko@gmail.com, \\ Kyiv National University of Culture and Arts, \\ Kyiv, Ukraine
}

\section{- Abstract}

The purpose of the article is to provide an analytical consideration of the concept of "show", reveal the functions and essential features of concert shows in modern popular culture. The research methodology is based on a systematic approach, which allowed us to reveal the relationships between different types of shows, identify and conceptualise their functional characteristics; analytical and comparative analyses are used to clarify the conceptual apparatus. The scientific novelty of research findings is to clarify the essential features of a show as a cultural product of mass society, such as publicity, mass character, entertainment, high technological effectiveness, orientation towards the viewer, beauty, which is manifested in the state of the artist and the external entourage. Conclusions. It is claimed that technological achievements, democratic transformations, urban processes of the $19^{\text {th }}-20^{\text {th }}$ centuries became the basis for the creation of new socio-economic relations, the manifestation of a new type of culture mass culture, which led to the development of new trends in culture and art. The author of the article analyses the multiple meaning of the term "show" in the cultural discourse: television and radio programme, theatrical performance, mass spectacle, fashion show could be referred to as shows. It is determined that a concert show is understood as a concert programme - solo or group, which is characterised by entertainment, mass character, brightness, and technological effectiveness of means of expression. A modern show is more "how?" than "what?", that is, extremely spectacular, pompous, exciting, colourful, dynamic, and original, because the modern audience strives for unforgettable impressions. The article highlights the main functions of the show: hedonistic, compensatory, communicative, informative, and cognitive, the function of emotional regulation. It is noted that the concert show should contribute to the development of the creative potential of the audience, expand the worldview, and provide new information. Raising the level of society's general culture could be considered as the highest objective of the organisers of the show.

Keywords: show; spectacle; concert show; mass culture 


\title{
ШОУ КАК ФЕНОМЕН МАССОВОЙ КУЛЬТУРЫ: СУЩНОСТНЫЕ ПРИЗНАКИ И ФУНКЦИИ
}

\author{
- Кириченко Алена Олеговна \\ - Аспирантка, \\ ORCID: 0000-0002-6237-832X, e-mail: alenakiri4enko@gmail.com, \\ Киевский национальный университет культуры и искусств, \\ Киев, Украина
}

\section{Аннотация}

Цель статьи - аналитически осмыслить значение понятия «шоу», раскрыть функции и сущностные признаки концертных шоу в современной массовой культуре. Методология исследования основана на системном подходе (для раскрытия взаимосвязи между различными видами шоу, выявления и концептуализации их функциональных характеристик); аналитическом и компаративном анализе (для уточнения понятийного аппарата). Научная новизна исследования заключается в выяснении сущностных черт шоу как культурного продукта массового общества, таких как публичность, массовость, зрелищность, высокая технологичность, ориентация на зрителя, красота, которая проявляется в состоянии артиста и внешнем антураже. Выводы. Отмечено, что технические открытия, демократические преобразования, урбанистические процессы

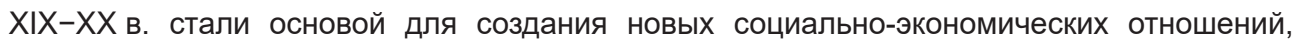
проявления нового типа культуры - массовой, что привело к развитию новых тенденций в культуре и искусстве. Проанализирована многозначность термина «шоу» в культурологическом дискурсе: шоу может называться телевизионная, радиопрограмма, театральное представление, массовое зрелище, модный показ. Определено, что под концертным шоу понимается концертная программа - сольная или сборная, которая отмечается зрелищностью, массовостью, яркостью, технологичностью выразительных средств. Современное шоу - это больше «как?», чем «что?». То есть крайне эффектно, помпезно, увлекательно, разноцветно, динамично и оригинально, ведь современный зритель стремится к незабываемым впечатлениям. Выделены основные функции шоу: гедонистическая, компенсаторная, коммуникативная, информативная и познавательная функция эмоционального регулирования. Отмечено, что концертное шоу должно способствовать развитию творческого потенциала аудитории, расширять кругозор, предоставлять новую информацию. Наивысшей целью организаторов шоу можно считать повышение общей культуры общества.

Ключевые слова: шоу; зрелище; концертное шоу; массовая культура 